\title{
The Implementation of Padlet to Foster EFL Students' Achievement in Writing
}

\author{
Muh. Farid Sehuddin", Nurdin Noni, \& Baso Jabu \\ English Education Department, Universitas Negeri Makassar, Makassar, Indonesia
}

\begin{abstract}
This study is the quasi experimental research that aimed to know the effect of the implementation of Padlet to the students' achievement in writing. The implementation Padlet as independent variables and the students' achievement in writing as a dependent variable. The population in this research is all students class XI MIA MAN 1 Makassar that consist of eight classes. Class XI MIA 5 as a control group that consist of 30 students and class XI MIA 1 as an experiment group that consist of 30 students. The data of the research was obtained by the study results test on the subject of the velocity reaction for pre-test and posttest. The data was analyzed by writing test. Based on analysis of inferential statistics for writing achievement, the $\mathrm{P}=0.001$, and it less than $\square=0,05$ was obtained, it is means that the implementation Padlet is significantly influence to the students' achievement in writing of the students' class XI MIA 1 MAN I Makassar on the material subject of writing.
\end{abstract}

Keywords: Writing, Padlet Application, EFL Learners, E- Learning, TEFL.

\section{Introduction}

Writing is one of a productive skill in language skills. Writing is the expression of language that is used to convey and explain the idea in the form of letter, symbol, and word to the reader. The mastery to write effectively become an important role in our global community. This is as a reason the role of instruction in writing need to be increased in both second and foreign language education. Relationship within languages become more essential, as advances in transformation and technology which allow people from nations and cultures throughout the world can interact with each other (Sakkir, 2020). Richard (2001: 21) states that writing involves composing skills and knowledge about texts, contexts, and readers. The writers not only need realistic strategies for drafting and revising but also a clear understanding of genre to be able to structure their writing according to the context. It means that, they not only focus in grammatical and mechanic, but also, they give attention into meaningful particular context.

Unfortunately, most of the high school students still find some difficulties to express their ideas in English in written form Nurgiyantoro (2001: 269) argued that writing is a more difficult ability to master than three other abilities, namely listening, speaking, and reading. It can be influenced by internal and external factors. One of the external factors are the implementation of technologies in writing classroom.

There are many considerations about the effect of implementation technology, specially the online media. The improvement of students' motivation and how useful this online media if we can get the benefit of it, especially in terms of writing (Sakkir, 2021). One of them is Padlet Application, but there is no one that specifically conducts the research about the use of "Padlet" in teaching writing for English course, which is special produced for class with teacher and students. Lestari (2017) in her study "Implementing Padlet Application to Improve Writing Ability in English Writing Skill for Non-English Department Students" she said that those application can be implemented as

\footnotetext{
* Corresponding author.

E-mail address: faridjhe@gmail.com (Muh. Farid Sehuddin)
} 
online writing practices anytime that push students skill improve, the situation of wall in Padlet can stimulate students to explore their idea because they could upload video, recording, or picture suitable with topic.

Based on the consideration above, the researchers interest to engage the students of MAN 1 Makassar to write English on "Padlet" site in hope that they can gain motivation to express their ideas in English written form comfortably that then may foster their writing achievement. So, the researchers formulated research question as follow: "Does the implementation of Padlet foster the students' writing achievement?"

\section{Literature Review}

\subsection{Concept of Writing}

According to Oxford dictionary (1993), writing is the action, process or practice of writing: the occupation of a person who writes the use of written character for purposes of record, communication, and etc. Winter (1999), writing is more than picking up a pen and putting words on paper. Writing requires thought and planning if it is to mean anything to the receiver who reads it. Beginning writers run into difficulties because they often consider only themselves when they write. Based on explanation above the writer concludes that the writing is process of building the larger unit of ideas, thinking and feeling to express something.

There are five significant components of writing according to Jacobs et. Al (1981) they are: content, organization, vocabulary, language in use, and mechanic. The writing is a way of looking at writing instruction in which the emphasis is shifted from students' finished products to what students think and do as they write. Furthermore, Spivey (2006) state that writing activity generally requires several processes namely prewriting, drafting, revising, editing and publishing.

According to Alice Oshima and Ann Iiogue (1997: 21) a narration is a kind of writing in which you report events, and it shall be focus on prewriting, organization (time order words and phrase), grammar and mechanic (simple present, past tense, adverbs of frequency, and comma rule), sentence structure (compound sentences with and, but, so, and or; rules for using coordinating conjunctions), and the last about writing process. From the explanation above, it can be concluded that generally the generic structure of narrative consists of three stages; they are orientation, complication, and resolution. They must be integrated as a whole in order to make a complete story. In this model, teacher reads the text for students, and students are asked to identify the part of the narrative in order to develop awareness of generic structure. Next, teacher develops students' sociocultural perspective on the text by giving them the pattern of stages repeatedly. However, there is no perfect way of teaching narrative writing. Every way of teaching has strengths and weaknesses. Teachers may choose their own best ways to teach narrative writing without being worried about the weaknesses of the models. Nevertheless, to cover the weaknesses of the used method, the use of various teaching aids or media is needed to carry out activities which are involved in the method. In this regard, this study will apply genrebased teaching method to teach writing narrative text using the selected teaching aids.

\subsection{Concept of Padlet}

Padlet is a free online tool that is best described as an online notice board. Padlet can be used by students and teachers to post notes on a common page. The notes posted by teachers and students can contain links, videos, images and document files. When you registered with Padlet, you can create as many "walls" or online notice boards as you like. These walls can set to private or public, with each wall having separate privacy settings.

According to Smith and Mader (2016), the metacognitive processes behind students' thinking become apparent to teachers through the use tools such as Padlet. According to Fuchs (2014), Padlet can be used for a variety of classroom purposes. Teacher questions can be posted to the wall, as opposed to asked verbally to the class. Students then have the opportunity to not only submit their answer, but also to read and evaluate their classmate responses. Teachers can request that students copy and post related links and images for a given lesson. Padlet can also be used in place of the standard do-now or ticket out the door. 
While Fuchs (2014) discusses the benefit of Padlet serving as a FA app for teachers, possible challenges are presented. Teachers must rely on internet access to implement the app in their classroom, and the appropriateness of student responses may become an issue when they know their peers can read everything they post (Fuchs, 2014). Fuchs (2014) argues that it is essential teachers pursue new strategies that will reach all of their students, in turn, increasing their level of engagement in the classroom.

\section{Methodology}

The research design of this study takes the form of the quantitative research approach. This research applied total sampling to determine the population samples. In this research, the researchers applied quasi-experimental method which involved two groups. They were experimental group and control group. The experimental group received treatment by using Padlet, while the control group gave a treatment without using Padlet (conventional way). The researchers provided the same material for both the experimental group and control group. Both of the groups gave pre-test and post-test. Pre-test administered before the experimentation to assess the students' prior knowledge on writing skill and the post-test administered to measure the experimentation effects. The research design formulated as follows:

\begin{tabular}{|ccc|}
\hline $\mathrm{EG}=\mathrm{O} 1$ & $\mathrm{X} 1$ & $\mathrm{O} 2$ \\
$\mathrm{CG}=\mathrm{O} 1$ & $\mathrm{X} 2$ & $\mathrm{O} 2$ \\
\hline
\end{tabular}

Fig. 1. Research Design

(Gay et al, 2006: 255)

Symbol:

$\begin{array}{ll}\text { EG } & \text { : Experimental Group } \\ \text { CG } & \text { : Control Group } \\ \text { O1 } & \text { : Pre-test } \\ \text { O2 } & \text { : Post-test } \\ \text { X1 } & \text { : Treatment for experimental group by the implementation of Padlet. } \\ \text { X2 } & \text { : Treatment for control group without the implementation of Padlet (conventional) }\end{array}$

This research consisted of two variables namely the implementation of Padlet as an independent variable and students' writing achievement as dependent variable. The population of the research was the first semester of the second grade of students in MAN 1 Makassar academic year 2018/2019. There were 8 classes with number of population were 240 students. The sampling technique of this research was cluster random sampling. For this research, the researchers were randomly select two classes, one class includes all students in the class as the experimental group, and another class includes all students in the class the control group. The researchers used the following instruments to achieve the purpose of the study is writing test. Writing test designed and developed by the researchers. The test consisted of four ideas of narrative texts.

The procedure of collecting the data was presented in the chronological order as follow: (1) Pre-test, before presenting the materials, the researchers gave pre-test to both experimental group and control group, the writing test to know the students' writing ability before treatment, and questionnaire to know the students' prior motivation, and (2) Post-test, after conducting the treatment, the post-test would give to both experimental and control groups, they were motivation questionnaires and writing test. Post-test gave to know the students' writing achievement after the treatment to see the effectiveness of using "Padlet" in motivating students to write English. The test item and procedures in the post-test were exactly the same as those in the pre-test.

In scoring students' answer the researchers used analytic scale, that benefit more to EFL program that holistic scale. Scale was rated on five aspects of writing: content, organization, vocabulary, language use, and mechanics. Each writing component have four rating levels of very poor, poor to fair, average to good, and very good to excellent. 
Each component and level had clear descriptors of the writing proficiency for that particular level as well as a numerical scale (Jacobs et al., 1981).

The data got from conversion was classified into five levels as shown in the following table:

Table 1. The scoring Classification of the students writing achievement

\begin{tabular}{ccc}
\hline No & Score & Classification \\
\hline 1 & $85-100$ & Very Good \\
2 & $76-84$ & Good \\
3 & $66-75$ & Average \\
4 & $56-65$ & Poor \\
5 & $<56$ & Very Poor \\
\hline
\end{tabular}

(Depdiknas, 2008)

In calculating the mean score, standard deviation, and t-test value (at significant level 0.05) by using independent ttest to see the difference between the two pre-tests and post-tests in experimental and control group, the researchers would use SPSS program version 25.

\section{Findings and Discussions}

The findings of the research consist of the pre-test and post-test score of experimental group and control group of students' writing achievement. The students' score described the overall students' English writing achievement about the percentage, the frequency, the mean score, the standard deviation and the test of significant.

\subsection{Scoring classification of the students' writing achievement}

The frequency of the percentage of the students' writing achievement in pre-test for both experimental and control group can be seen in table below, as follow:

Table 2. The Frequency and the percentage of the students' writing achievement score in pre-test

\begin{tabular}{|c|c|c|c|c|c|}
\hline \multicolumn{6}{|c|}{ PRE-TEST } \\
\hline \multirow{2}{*}{$\begin{array}{l}\text { Range } \\
\text { of Score }\end{array}$} & \multirow{2}{*}{ Classification } & \multicolumn{2}{|c|}{ Experimental Group } & \multicolumn{2}{|c|}{ Control Group } \\
\hline & & Frequency & Percentage & Frequency & Percentage \\
\hline $85-100$ & Very Good & 1 & $3 \%$ & 8 & $27 \%$ \\
\hline $76-84$ & Good & 7 & $23 \%$ & 8 & $27 \%$ \\
\hline $66-75$ & Average & 12 & $40 \%$ & 7 & $23 \%$ \\
\hline $56-65$ & Poor & 7 & $23 \%$ & 0 & $0 \%$ \\
\hline$<56$ & Very Poor & 3 & $10 \%$ & 7 & $23 \%$ \\
\hline & Total & 30 & $100 \%$ & 30 & $100 \%$ \\
\hline
\end{tabular}

Table 2 shows that the score of experimental group was categorized as average category. In experimental group, there is only1 student that was categorized as very high achievement students. There are 7 students that were categorized as good classification. There are 12 students that were categorized as average classification. There are 7 students that were categorized as poor classification. There are 3 students that were categorized as very poor classification.

While in the control group, there are 8 students that were categorized as very high achievement students, it means that $27 \%$ of the students got very good writing achievement. There are 8 students that were categorized as good 
classification. There are 7 students that were categorized as average classification. There is no one of the students that was categorized as poor classification. There are 7 students that were categorized as very poor classification.

The frequency of the percentage of the students' writing achievement in post-test for both experimental and control group can be seen in table below, as follow:

Table 3. The Frequency and the percentage of the students' writing achievement score in post-test

\begin{tabular}{cccccc}
\hline \multirow{2}{*}{ Range of Score } & Classification & \multicolumn{2}{c}{ Experimental Group } & \multicolumn{2}{c}{ Control Group } \\
\cline { 3 - 6 } & & Frequency & Percentage & Frequency & Percentage \\
\hline $85-100$ & Very Good & 20 & $67 \%$ & 7 & $23 \%$ \\
$76-84$ & Good & 9 & $30 \%$ & 19 & $63 \%$ \\
$66-75$ & Average & 1 & $3 \%$ & 3 & $10 \%$ \\
$56-65$ & Poor & 0 & $0 \%$ & 1 & $3 \%$ \\
$<56$ & Very Poor & 0 & $0 \%$ & 0 & $0 \%$ \\
\hline & & 30 & $100 \%$ & 30 & $100 \%$ \\
\hline
\end{tabular}

Table 3 shows that the score of experimental group was categorized as very good category. In experimental group, there 20 students that were categorized as very high achievement students, it means that $67 \%$ of the students got very good writing achievement. There are 9 students that were categorized as good classification; it means that $30 \%$ of the students got good writing achievement. There is only one student that was categorized as average classification; it means that there is only $3 \%$ of the student got average writing achievement. None of the students that was categorized as poor and very poor classification.

While the score of control group was categorized as good category. In the control group, there are 7 students that were categorized as very high achievement students; it means that $23 \%$ of the students got very good writing achievement. There are 19 students that were categorized as good classification; it means that $63 \%$ of the students got good writing achievement. There is no one of the students that was categorized as very poor classification; it means that there is $0 \%$ of students got very poor writing achievement.

\subsection{The student' means score and standard deviation of students' writing achievement}

The mean score and standard deviation in pre-test of both experimental and control group for writing achievement can be seen in the table below, as follow:

Table 4. Mean score and standard deviation of students' writing achievement in pre-test

\begin{tabular}{|c|c|c|c|c|c|}
\hline \multicolumn{6}{|c|}{ Group Statistics } \\
\hline Class & & $\mathrm{N}$ & Mean & $\begin{array}{c}\text { Std. } \\
\text { Deviation }\end{array}$ & Std. Error Mean \\
\hline \multirow{2}{*}{ Pre-test Writing Test } & Experimental & 30 & 30 & 69.1667 & 9.76300 \\
\hline & Control & 30 & 30 & 69.5667 & 21.07733 \\
\hline
\end{tabular}

Table 4 shows that the mean score on the pre-test obtained in the students' writing achievement for experimental group was 69.16 (Average) with standard deviation 9.763 while the control group was 69.56 (Average) with standard deviation 21.077 .

The mean score and standard deviation in post-test of both experimental and control group for writing achievement can be seen in the table below, as follow: 
Table 5. Mean score and standard deviation of students' writing achievement in post-test

\begin{tabular}{lccccc}
\hline \multicolumn{7}{c}{ Group Statistics } \\
\hline \multicolumn{1}{c}{ Class } & & $\mathrm{N}$ & Mean & $\begin{array}{c}\text { Std. } \\
\text { Deviation }\end{array}$ & $\begin{array}{c}\text { Std. Error } \\
\text { Mean }\end{array}$ \\
\hline \multirow{2}{*}{ Post-test Writing Test } & Experimental & 30 & 86.9000 & 4.55881 & 0.83232 \\
& Control & 30 & 81.4333 & 6.72455 & 1.22773 \\
\hline
\end{tabular}

Table 5 shows that the mean score on the post-test obtained in the students' writing achievement for experimental group was 86.90 (Average) with standard deviation 4.558 while the control group was 81.43 (Average) with standard deviation 6.724 .

\subsection{General guidelines for the preparation of your text}

After seeing the students' writing achievement in general, the researcher then wanted to see the students score in five aspects of writing achievement, they are: content, organization, vocabulary, language use, and mechanics. It can be seen in the table below, as follow:

Table 6. Mean and standard deviation score on five aspects of students writing achievement

\begin{tabular}{|c|c|c|c|c|c|c|c|c|}
\hline \multirow{3}{*}{ Aspects } & \multicolumn{5}{|c|}{ Experimental Group } & \multicolumn{3}{|c|}{ Control Group } \\
\hline & \multicolumn{2}{|c|}{ Pre-test } & \multicolumn{2}{|c|}{ Post-test } & \multicolumn{2}{|c|}{ Pre-test } & \multicolumn{2}{|c|}{ Post-test } \\
\hline & Mean & SD & Mean & SD & Mean & SD & Mean & SD \\
\hline Content & 20.6667 & 3.50697 & 26.3333 & 1.76817 & 22.1667 & 5.60839 & 24.1333 & 2.88556 \\
\hline Organization & 14.6000 & 2.31338 & 17.8000 & 0.61026 & 13.9333 & 4.16830 & 16.9667 & 1.37674 \\
\hline Vocabulary & 15.1333 & 2.41737 & 17.7333 & 1.20153 & 14.4333 & 4.47740 & 16.8667 & 1.56983 \\
\hline $\begin{array}{l}\text { Language } \\
\text { Use }\end{array}$ & 15.7000 & 3.45563 & 21.2000 & 2.02399 & 15.6667 & 6.62978 & 20.0333 & 2.67148 \\
\hline Mechanics & 3.0667 & 0.44978 & 3.8333 & 0.37905 & 3.3667 & 1.06620 & 3.4333 & 0.56832 \\
\hline Total & 69.1667 & 12.1431 & 86.9000 & 5.9830 & 69.5667 & 21.9501 & 81.4333 & 9.0719 \\
\hline
\end{tabular}

Mean score and standard deviation for both groups, based on the scoring aspects of motivation. In the content, the mean score for experimental group in pre-test was 20.66 with standard deviation 3.506 and in the post-test were 26.33 
with standard deviation 1.768. It means that there was improvement from pre-test to post-test. While the mean score for control group in the pre-test was 22.16 with standard deviation 5.608 and in the post-test were 24.13 with standard deviation 2.885 .

In the organization, the mean score for experimental group in pre-test was 14.60 with standard deviation 2.313 and in the post-test were 17.80 with standard deviation 0.610 . It means that the score is decrease from pre-test to post test. While the mean score for control group in the pre-test was 13.93 with standard deviation 4.168 and in the post-test were 16.96 with standard deviation 1.376.

In the vocabulary, the mean score for experimental group in pre-test was 15.13 with standard deviation 2.417 and in the post-test were 17.73 with standard deviation 1.201. While the mean score for control group in the pre-test was 14.43 with standard deviation 4.477 and in the post-test were 16.86 with standard deviation 1.569. It means that there was improvement between pre-test and post-test.

In the language use, the mean score for experimental group in pre-test was 15.70 with standard deviation 3.455 and in the post-test were 21.20 with standard deviation 2.023. It means that there is improvement from pre-test to post test. While the mean score for control group in the pre-test was 15.66 with standard deviation 6.629 and in the post-test were 20.03 with standard deviation 2.671. It means that there was improvement between pre-test and post-test.

In the mechanics, the mean score for experimental group in pre-test was 3.06 with standard deviation 0.449 and in the post-test were 3.83 with standard deviation 0.379 . While the mean score for control group in the pre-test was 3.36 with standard deviation 1.066 and in the post-test were 3.43 with standard deviation 0.568 . It means that there was improvement between pre-test and post-test.

After analyzing the students' writing achievement generally, the researcher then concerned to each component of writing achievement, they are: content, organization, vocabulary, language use, and mechanics (Jacobs, 1981). In writing achievement, there is only one of components in writing achievement that was not increased significantly, that was language use. It means that after the implementation of Padlet, the components of writing achievement were increased, except in language use. It indicates that the students have low ability to construct their writing. Such as tenses, word order/ function and article. It is related to the Jacob's theory that he divided writing achievement into 5 (five) kinds, they are content, organization, vocabulary, language use, and mechanics.

\section{Conclusions}

Based on the findings and discussion of the study it can be concluded that the implementation of Padlet is an effective technique in fostering the students' English writing achievement of the students' class XI MIA 1 MAN I Makassar. The implementation of Padlet on the students' writing achievement was significantly different from another way (Conventional way). There was significant difference in all the aspects (content, organization, vocabulary, language use, and mechanics). It was proved by the score of the experimental group in the pre-test which was not significantly different with control group $(69.16<69.59)$. While in post-test the score of experimental group was significantly different than control group (86.90>81.43).

\section{Acknowledgements}

The research was supported by Universitas Negeri Makassar as affiliation research for the academic support. We would also like to show our gratitude to all teachers of MAN 1 Makassar for sharing their perceptions and knowledge for the purpose of this study. 


\section{References}

Atmowardoyo, H., Weda, S., \& Sakkir, G. (2020). Information Technology used by Millennial Good English Language Learners in an Indonesian University to Improve their English Skills. Solid State Technology, 63(5), 9532-9547.

Atmowardoyo, H., Weda, S., \& Sakkir, G. (2021). Learning Strategies in English Skills used by Good Language Learners in Millennial Era: A Positive Case Study in Universitas Negeri Makassar. ELT Worldwide: Journal of English Language Teaching, 8(1), 28-40.

Bacha, N. (2001). Writing evaluation : what can analytic versus holistic essay scoring tell Us?. Lebanon: Elsevier science Ltd. Lebanese American university.

Depatemen Pendidikan Nasional. (2008). Metode penilaian kelas kurikulum berbasis kompetensi. Depdiknas: Jakarta.

Dollah, S. (2016). THE EFFECT OF SELF-ESTEEM, ANXIETY, AND GENDER ON ORAL COMMUNICATION OF EFL LEARNERS (Penghargaan Diri, Kecemasan, dan Jenis Kelamin terhadap Komunikasi Lisan Pebelajar Bahasa Inggris sebagai Bahasa Asing). SAWERIGADING, 15(3), 349-360.

Fiester, H. and Green, T. (2016). Student use of backchannels. TechTrends, 60(4), pp. 404-408. doi: 10.1007/s11528016-0069-9.

Fuchs, Beth. (2014). The Writing is on the Wall. Using padlet for Whole-Class Engagement. Kentucky. University of Kentucky.

Gay, L.R., et.al. (2006). Educational research: competencies for analysis and application (eight edition), Columbus: pearson prentice hall

Harmer, J. (1991). The practice of English language teaching. London: Longman.

Heaton, J. B. (1988). Writing English language tests. London: Longman.

Jacobs, H.; Zingraf, S.; Wormuth, D.; Hartfiel, V.F., \& Hughey, J. (1981). ESL Composition Profile. Newbury House Publishers.

Kasmawati, K., \& Sakkir, G. (2020). IMPROVING STUDENTS READING COMPREHENSION THROUGH "SURVEY, QUESTION, READING, RECITE, REVIEW (SQ3R)" STRATEGY. Interference: Journal of Language, Literature, and Linguistics, 1(2), 92-99.

Lestari, S. (2017). Implementing Padlet Application To Improve Writing Ability In English Writing Skill For Non English Department Students. Universitas PGRI Madiun. Madiun.

Mader, J. and Smith, B. (2016). Science 2.0: Mastering scientific practices with technology, part 2. The Science Teacher, 083(03), p. 8. doi: 10.2505/4/tst16_083_03_8.

Nurgiyantoro, B. (2001). Penilaian dalam Pengajaran Bahasa dan Sastra. Yogyakarta: BPFE.

Nurlaelah, N., \& Sakkir, G. (2020). Model Pembelajaran Respons Verbal dalam Kemampuan Berbicara. Edumaspul: Jurnal Pendidikan, 4(1), 113-122.

Oshima, A., \& Hogue, A. (1997). Introduction to Academic Writing 2nd ed. New York: Addison Wesley Longman.

Rahman, H., Sakkir, G., \& Khalik, S. (2020). Audio-Lingual Method to Improve Students's Speaking Skill at Smp Negeri 1 Baranti. La Ogi: English Language Journal, 6(1), 15-21.

Richard, J.C. (2001). 30 Years of TEFL/TESL: A Personal Reflection. Singapura.

Ririantika, R., Usman, M., Aswadi, A., \& Sakkir, G. (2020). PENERAPAN MODEL PEMBELAJARAN TIPE "MAKE A MATCH" TERHADAP HASIL BELAJAR BAHASA INDONESIA SISWA KELAS VIII SMP NEGERI 1 BARANTI KABUPATEN SIDENRENG RAPPANG. Cakrawala Indonesia, 5(1), 1-6.

Sakkir, G. (2018). Writing: Beginner. Deepublish. 
Sakkir, G., \& Dollah, S. (2019). FACEBOOK-BASED WRITING INSTRUCTIONAL MATERIAL IN ENGLISH CLASS: LECTURERS'PERCEPTION. Seltics, 2(2), 76-83.

Sakkir, G., \& Dollah, S. (2019). Measuring students'writing skills using Facebook group application in EFL context. International Journal of Humanities and Innovation (IJHI), 2(3), 69-72. https://doi.org/10.33750/ijhi.v2i3.43

Sakkir, G., \& Usman, M. (2018). MOVIE IN ENHANCING STUDENTS'VOCABULARY. Eralingua: Jurnal Pendidikan Bahasa Asing dan Sastra, 2(2).

Sakkir, G., Dollah, S., \& Ahmad, J. (2020). Favorite E-Learning Media in Pandemic Covid-19 Era. Jurnal Studi Guru Dan Pembelajaran, 3(3), 480-485.

Sakkir, G., Dollah, S., \& Ahmad, J. (2021). CHARACTERISTICS OF A GOOD EFL TEACHER: INDONESIAN EFL STUDENTS PERSPECTIVES. JURNAL NALAR PENDIDIKAN, 9(1), 52-59.

Sakkir, G., Dollah, S., \& Ahmad, J. (2021). E-Learning in COVID-19 Situation: Students' Perception. EduLine: Journal of Education and Learning Innovation, 1(1), 9-15.

Sakkir, G., Dollah, S., Arsyad, S., \& Ahmad, J. (2021). Need Analysis for Developing Writing Skill Materials Using Facebook for English Undergraduate Students. International Journal of Language Education, 5(1), 542-551.

Sakkir, G., Zulfirman, Z., Mahmud, N., \& Ahmad, J. (2020). Improving speaking ability using English" Shock Day" approach. International Journal of Humanities and Innovation (IJHI), 3(2), 56-59.

Saputra, U. R., Maulina, M., Nasrullah, R., \& Sakkir, G. (2021). Students' Sentence Errors on WhatsApp Daily Status: A Literature Review. Celebes Journal of Language Studies, 23-31.

Spivey, B. (2006). What is the Writing Process? Retrieved from http://www.superduperinc.com/handouts/pdf/112_Writing_Process.pdf.

Syatriana, E., \& Sakkir, G. (2020). Implementing Learning Model Based on Interactive Learning Community for EFL Students of Muhammadiyah University. ELT Worldwide: Journal of English Language Teaching, 7(1), 24-30.

Weigle, S. C., (2002). Assessing Writing. Cambridge Language AssessmentSeries. United Kingdom: Cambridge University Press.

Winter, R., Buck, A. and Sobiechowska, P. (1999). Professional Experience and the Investigative Imagination. London: Routledge.

Yunus, Y., Dollah, S., \& Munir, M. (2021). The Use of Four-Square Technique to Improve Students' Writing Ability. Tamaddun, 20(1), 1-14. 